\title{
PENGARUH PRODUKTIVITAS, EFISIENSI DAN KEPUASAN KERJA TERHADAP PERPUTARAN KARYAWAN BAGIAN MARKETING LEMPUK SYAKO MAKASSAR
}

\author{
Hamsinah. $\left.{ }^{*}\right)$ \\ Email : inabaharuddin12@gmail.com
}

\begin{abstract}
ABSTRAK
PENGARUH PRODUKTIVITAS, EFISIENSI, KEPUASAN KERJA TERHADAP PERPUTARAN KARYAWAN BAGIAN MARKETING LEMPUK SYAKO MAKASSAR. Perusahaan dapat menjadi besar apabila didukung oleh sumber daya manusia yang berkualitas, oleh karena itu sumber daya manusia merupakan dasar dari segala aktivitas produksi yang harus dapat ditingkatkan dan dikembangkan agar produktivitas, efisiensi, dan kepuasan kerja dapat dirasakan oleh karyawan. Penelitian ini bertujuan untuk mengetahui pengaruh produktivitas kerja, efisiensi kerja, dan kepuasan kerja secara simultan maupun parsial terhadap perputaran karyawan. Sampel penelitian ini adalah 114 karyawan. Teknis analisis menggunakan analisis regresi linier berganda, uji $F$ dan uji t. Hasil penelitian ini menunjukkan bahwa produktivitas, efisiensi, kepuasan kerja secara simultan berpengaruh signifikan terhadap perputaran karyawan, hal ini dibuktikan dengan uji $F$ yang menunjukkan nilai signifikansi 0,000 lebih kecil dari 0,05 dan uji $t$ yang menunjukkan signifikansi semua variabel bebas lebih dari 0,05 yaitu sebesar 0,037 untuk variabel produktivitas kerja, 0,046 untuk variabel efisiensi kerja, dan 0,042 untuk variabel kepuasan kerja. Dari hasil pengujian dengan uji t juga dapat diketahui bahwa variabel yang mempunyai pengaruh dominan terhadap perputaran karyawan adalah produktivitas kerja karena mempunyai nilai signifikansi yang lebih kecil dari pada variabel efisiensi kerja dan kepuasankerja.
\end{abstract}

Kata kunci : produktivitas kerja, efisiensi kerja, kepuasan kerja, perputaran karyawan

\begin{abstract}
EFFECTIVENESS OF PRODUCTIVITY, EFFICIENCY, WORK SATISFACTION TO EMPLOYEE EMPLOYEES MAKE SECTION MARKETING SYAKO MAKASSAR. A company can turn into big company when it is supported by qualified human resources, therefore human resources are the basis of all production activities which can be improved and developed so the productivity, efficiency, and job satisfaction can be felt by all employees. This research is meant to find out the influence of labor productivity, work efficiency, and job satisfaction either simultaneous or partial to the turnover of employees. The samples are 114 employees. The analysis technique has been carried out multiple linear regressions, $F$ test and $t$ test. The result of this research shows that simultaneously productivity, efficiency, job satisfaction have significant influence to the turnover of employees, it has been proven by $F$ test which shows the significance value 0.000 which is smaller than 0.05 and $t$ test which shows the significance of all independent variables are more than 0.05 which is 0.037 for labor productivity variable, 0.046 for work efficiency variable, and 0.042 for job satisfaction variable. It can be known from the result of $t$ test that the variable which has dominant influence to the turnover of the employees is labor productivity since its significant value is smaller than work efficiency and job satisfaction variables.
\end{abstract}

Keywords: Labor Productivity, Work Efficiency, Job Satisfaction, Turnover of Employees

*) Dosen Program Studi Magister Manajemen - UNPAM 


\section{PENDAHULUAN}

Dalam rangka menghadapi perubahan dan persaingan bisnis yang semakin ketat antar perusahaan, maka diperlukan sumber daya manusia yang berkualitas. Kondisi lingkungan yang harus dihadapi oleh manajemen sumber daya manusia sangatlah menantang karena perubahan yang seringkali terjadi sangat cepat dengan berbagai masalah yang kompleks dan rumit. Perusahaan harus memiliki sumber daya yang baik, khususnya sumber daya manusia yang berkualitas agar dapat bersaing di era global.

Perusahaan dapat menjadi besar apabila didukung oleh sumber daya manusia yang berkualitas. Manusia sebagai pelaksana kerja, maka sasaran dan tujuan yang telah ditetapkan oleh suatu perusahaan tidak mungkin tercapai sesuai dengan yang diharapkan, jika sumber daya manusia yang berkualitas tinggi tidak memberikan sumbangan yang besar terhadap keberhasilan pencapaian dan tujuan perusahaan, oleh karena itu sumber daya manusia merupakan dasar dari segala aktivitas produksi yang harus dapat ditingkatkan dan dikembangkan agar kepuasan kerja dapat dirasakan olehkaryawan.

Produktivitas mempunyai kaitan yang erat dengan keinginan atau kemauan seseorang untuk mencapai sesuatu yang lebih baik. Menurut Siagian (2003:154) Produktivitas adalah kemampuan memperoleh manfaat sebesar-besarnya dari sarana dan prasarana yang tersedia dengan menghasilkan keluaran (output) yang optimal bahkan kalau mungkin yang maksimal.

Produktivitas kerja merupakan suatu masalah yang harus mendapat perhatian serius dari pihak perusahaan, karena peningkatan produktivitas kerja karyawan tidak akan terjadi dengan sendirinya, tetapi harus ada usaha dan peran serta baik dari pihak perusahaan maupun dari pihak karyawan itu sendiri.

Efisiensi kerja merupakan suatu prinsip dasar untuk melakukan setiap kegiatan suatu perusahaan dengan tujuan untuk dapat memperoleh hasil yang dikehendaki dengan usaha yang seminimal mungkin seusai dengan standar yang ada. Menurut Sedarmayanti (2001:112) Efisiensi kerja adalah perbandingan terbaik antara suatu pekerjaan yang dilakukan dengan hasil yang dicapai oleh pekerjaan tersebut sesuai dengan yang ditargetkan baik dalam hal mutu maupun hasilnya yang meliputi pemakaian waktu yang optimal dan kualitas cara kerja yang maksimal.

Bekerja dengan efisiensi adalah bekerja dengan gerakan, usaha, waktu dan kelelahan yang sedikit mungkin. Dengan menggunakan cara kerja yang sederhana, penggunaan alat yang dapat membantu mempercepat penyelesaian tugas serta menghemat gerak dan tenaga, maka seseorang dapat dikatakan bekerja dengan efisien dan memperoleh hasil yang memuaskan.

Salah satu sasaran manajemen sumber daya manusia dalam suatu perusahaan adalah terciptanya kepuasan kerja anggota organisasinya. Kepuasan kerja karyawan yang tinggi cenderung akan meningkatkan produktivitas kerja karyawan yang juga akan berdampak positif pada pencapaian tujuan perusahaan. Menurut Siagian (2006:295) berpendapat bahwa kepuasan kerja merupakan suatu cara pandang seseorang, baik yang bersifat positif maupun bersifat negatif tentang pekerjaannya.

Karyawan yang merasakan kepuasan dalam bekerja, dapat diketahui dari rendahnya tingkat perputaran karyawan dan tingginya tingkat produktivitas. Ketidakpuasan karyawan dalam bekerja dapat menimbulkan berbagai dampak negatif, seperti mangkir kerja dengan berbagai alasan dan tidak tepat waktu sesuai dengan 
target yang sudah ditetapkan dalam menyelesaikan pekerjaan.

Perputaran karyawan dapat terjadi di antara karyawan yang merasa puas karena tertarik oleh harapan yang sangat positif mengenai pekerjaan di luar atau yang memutuskan untuk mengikuti nilai-nilai yang tidak ada kaitannya dengan pekerjaan. Apabila seseorang ingin meninggalkan pekerjaan yang tidak disenangi (tetapi terkendala oleh beberapa sebab, misalnya: kurangnya pekerjaan yang menarik, faktorfaktor ekstern seperti karier pasangan hidup dan lain-lain), maka bentuk perputaran karyawan dan pengunduran diri dapat berupa kemangkiran, kelesuan dan sebagainya.

Sebagian besar perusahaan mengidentifikasikan penyebab utama tingginya angka perputaran karyawan karena adanya gaji yang tidak kompetitif dibandingkan dengan perusahaan lain. Hal ini diikuti dengan rendahnya semangat kerja ditempat kerja, tidak ada kesempatan untuk maju, komunikasi yang buruk, ketidak acuhan manajer atau perusahaan, dan adanya rasa jemu pada diri karyawan. Dalam tingkat posisi yang lebih rendah, penyebabnya adalah adanya lingkungan kerja yang buruk, praktek perekrutan karyawan yang buruk, prosedur perusahaan yang buruk dan insentif yang jelek (Grensing, 1997:141).

Penelitian mengenai produktivitas kerja, efisiensi kerja, dan kepuasan kerja merupakan suatu penelitian yang menarik untuk mengetahui bagaimana cara seorang manajer melihat tingkat produktivitas, efisiensi, dan kepuasan kerja yang dialami oleh para karyawan dalam mencapai target yang ditetapkan oleh perusahaan serta dapat menekan perputaran karyawan pada tiap tahunnya.

Berdasarkan latar belakang tersebut maka rumusan masalah dalam penelitian ini adalah apakah produktivitas, efisiensi, dan kepuasan kerja mempengaruhi perputaran karyawann bagian marketing dan penelitian ini bertujuan untuk mengetahui pengaruh produktivitas, efisiensi, kepuasaan kerja terhadap perputaran karyawan bagian marketing. Pada penelitian ini, membatasi faktor-faktor yang mempengaruhi perputaran karyawan hanya pada faktor-faktor produktivitas kerja, efisiensi kerja, dan kepuasan kerja. Apabila terdapat faktor-faktor lain yang berpengaruh terhadap perputaran karyawan, tidak melakukan penelitian pada faktor-faktor tersebut.

\section{TINJAUAN TEORITIS DAN HIPOTESIS}

\section{A. TINJAUAN TEORI}

\section{Teori Produktivitas}

Produktivitas secara umum diartikan sebagai hubungan antara keluaran (barangbarang atau jasa) dengan masukan (tenaga kerja, bahan, uang). Produktivitas adalah ukuran efisiensi produktif. Suatu perbandingan antara hasil keluaran dan masukan. Masukan sering dibatasi dengan tenaga kerja, sedangkan keluaran diukur dalam kesatuan fisik, bentuk dan nilai.

Menurut Tohardi (dalam Sutrisno, 2010:106) Produktivitas kerja merupakan sikap mental. Sikap mental yang selalu mencari perbaikan terhadap apa yang telah ada. Suatu keyakinan bahwa seseorang dapat melakukan pekerjaan lebih baik hari ini daripada hari kemarin dan hari esok lebih baik daripada hari ini.

Pendapat tersebut didukung oleh Ravianto (dalam Sutrisno, 2010:106), mengatakan produktivitas pada dasarnya mencakup sikap mental yang selalu 
mempunyai pandangan bahwa kehidupan hari ini harus lebih baik dari hari kemarin dan hari esok harus lebih baik dari hari ini. Sikap yang demikian akan mendorong seseorang untuk tidak cepat merasa puas, akan tetapi harus mengembangkan diri dan meningkatkan kemampuan kerja dengan cara selalu mencari perbaikan-perbaikan dan peningkatan.

Menurut Singodimedjo (dalam Sutrisno, 2010:107) Ada tiga aspek utama yang perlu ditinjau dalam menjamin produktivitas yang tinggi, yaitu: (a) aspek kemampuan manajemen tenaga kerja, (b) aspek efisiensi tenaga kerja, dan (c) aspek kondisi lingkungan pekerjaan. Ketiga aspek tersebut saling terkait dan terpadu dalam suatu system dan dapat diukur dengan berbagai ukuran yang relative sederhana. Produktivitas harus menjadi bagian yang tidak boleh dilupakan dalam penyusunan strategi bisnis, yang mencakup bidang produksi, pemasaran, keuangan dan bidang lainnya.

Selanjutnya dijelaskan bahwa orang yang mempunyai sikap tersebut terdorong untuk menjadi dinamis, kreatif, inovatif, serta terbuka, namun tetap kritis dan tanggap terhadap ide-ide baru dan perubahan-perubahan. Dalam kaitannya dengan tenaga kerja, maka produktivitas tenaga kerja merupakan perbandingan antara hasil yang dicapai dengan peran serta tenaga kerja per satuan waktu.

Dari beberapa pengertian tersebut di atas, penulis menyimpulkan bahwa produktivitas kerja terdiri dari tiga aspek, yaitu pertama produktivitas adalah keluaran fisik per unit dari usaha produktif; Kedua produktivitas adalah keefektifan dari penggunaan tenaga kerja dan peralatan. Tetapi intinya semua mengarah pada tujuan yang sama, bahwa produktivitas kerja adalah rasio dari hasil kerja dengan waktu yang dibutuhkan untuk menghasilkan produk dari seseorang tenagakerja.

Dalam upaya meningkatkan produktivitas kerja karyawan disuatu perusahaan perlu memperhatikan faktor-faktor yang mempengaruhi produktivitas kerja karyawan tersebut. Banyak faktor yang dapat mempengaruhi produktivitas kerja karyawan baik yang berhubungan dengan tenaga kerja itu sendiri maupun faktor-faktor yang berhubungan dengan lingkungan perusahaan dan kebijakan pemerintah secara keseluruhan.

Menurut Simanjuntak (dalam Sutrisno, 2010:109-120), ada beberapa faktor yang dapat mempengaruhi produktivitas kerja karyawan, yaitu :

(1) Pelatihan, latihan kerja dimaksudkan untuk melengkapi karyawan dengan keterampilan dan cara-cara yang tepat untuk menggunakan peralatan kerja. Untuk itu latihan kerja diperlukan bukan saja sebagai pelengkap akan tetapi sekaligus untuk memberikan dasar- dasar pengetahuan. Karena dengan latihan berarti para karyawan belajar untuk mengerjakan sesuatu dengan benar-benar dan tepat, serta dapat memperkecil atau meninggalkan kesalahan-kesalahan yang pernah dilakukan. (2) Mental dan kemampuan fisik karyawan, keadaan mental dan fisik karyawan merupakan hal yang sangat penting untuk menjadi perhatian bagi organisasi, sebab keadaan fisik dan mental karyawan mempunyai hubungan yang sangat erat dengan produktivitas kerja karyawan. (3) Hubungan antara atasan dan bawahan, hubungan atasan dan bawahan akan mempengaruhi kegiatan yang dilakukan sehari-hari. Bagaimana pandangan atasan terhadap bawahan, sejauh mana bawahan diikutsertakan dalam penetuan tujuan. Sikap yang saling jalin- menjalin telah mampu meningkatkan produktivitas karyawan dalam bekerja. Dengan demikian, jika karyawan diperlakukan 
secara baik, maka karyawan tersebut akan berpartisipasi dengan baik pula dalam proses produksi, sehingga akan berpengaruh pada tingkat produktivitaskerja.

Dengan demikian, jika karyawan diperlukan secara baik oleh atasan atau adanya hubungan antar karyawan yang baik, maka karyawan tersebut akan berpartisipasi dengan baik pula dalam proses produksi, sehingga akan berpengaruh pada tingkat produktivitas kerja.

\section{Teori Efisiensi}

Efisiensi maupun produktivitas keduanya dapat digunakan sebagai bahan untuk mengukur kinerja suatu unit kegiatan ekonomi, meskipun secara prinsip kedua pengukuran tersebut berbeda. Konsep efisiensi lebih berkaitan dengan seberapa jauh suatu proses mengkonsumsi masukan untuk menghasilkan keluaran tertentu, sementara konsep produktivitas berkaitan dengan seberapa jauh suatu proses menghasilkan keluaran dengan mengkonsumsi masukan tertentu (Mulyadi, 2000:437).

Pengertian efisiensi menurut Sedarmayanti (2001:112) pada prinsipnya adalah perbandingan terbaik antara hasil yang diperoleh dengan kegiatan yang dilakukan. Bekerja dengan efisiens adalah bekerja dengan gerakan, usaha, waktu dan kelehan yang sedikit mungkin. Dengan menggunakan cara kerja yang sederhana, penggunaan alat yang dapat membantu mempercepat penyelesaian tugas serta menghemat gerak dan tenaga, maka seseorang dapat dikatakan bekerja dengen efisien dan memperoleh hasil yang memuaskan.

Berdasarkan definisi diatas dapat disimpulkan bahwa dengan menggunakan cara kerja yang sederhana, penggunaan alat yang dapat membantu mempercepat penyelesaian tugas serta menghemat gerak dan tenaga, maka seseorang dapat dikatakan bekerja secara efisien dan memperoleh hasil yang memuaskan. Setiap karyawan yang tidak menyukai penghamburan akan bekerja dengan efisien. Karyawan yang efisien tidak akan mengeluh walaupun banyak yang harus dikerjakannya, akan tetapi karyawan yang tidak efisien akan mengeluh walaupun sedikit yang dikerjakannya. Karena itu penerapan tata kerja yang efisien hendaknya diterapkan secara terus menerus agar jiwa efisiensi benar-benar terbentuk dalam diri setiapkaryawan.

Banyak faktor yang mempengaruhi seseorang untuk dapat bekerja dengan efisien, diantaranya : (1) Berhasil guna/efektif, untuk menyatakan bahwa kegiatan telah dilaksanakan dengan tepat, artinya target tercapai sesuai dengan waktu yang ditetapkan. (2) Ekonomis, untuk menyebutkan bahwa di dalam usaha pencapaian efektif termaksud, maka biaya, tenaga kerja, material, peralatan, waktu, ruangan dan lain sebagainya, telah dipergunakan setepat- tepatnya. (3) Pelaksanaan kerja yang dapat dipertanggungjawabkan, untuk membuktikkan bahwa didalam pelaksanaan kerja, sumber-sumber telah dimanfaatkan dengan setepat- tepatnya dan dilaksanakan penuh tanggungjawab sesuai yang telah ditetapkan. (4) Pembagian kerja yang nyata, berdasarkan pemikiran bahwa tidak mungkin manusia seorang diri mengerjakan segala macam pekerjaan dengan baik, oleh sebab itu harus ada pembagian kerja yang nyata yaitu benar-benar berdasarkan beban kerja, ukuran kemampuan kerja dan waktu yang tersedia. (5) Rasionalitas wewenang dan tanggung jawab, jangan sampai terjadi, seseorang mempunyai wewenang yang lebih besar dari tanggung jawabnya, sebaliknya jangan sampai terjadi wewenang lebih kecil dari tanggung jawabnya. (6) 
Prosedur kerja yang praktis dapat dikerjakan dan dapat dilaksanakan, pelaksanaan kerja yang dapat dipertanggungjawabkan serta pelayanan kerja yang memuaskan tersebut, haruslah merupakan kegiatan operasional yang dapat dilaksanakan dengan lancar.

\section{Teori Kepuasan Kerja}

Salah satu sasaran manajemen sumber daya manusia dalam suatu perusahaan adalah terciptanya kepuasan kerja anggota organisasinya. Kepuasan kerja karyawan yang tinggi cenderung akan meningkatkan produktivitas kerja karyawan yang juga akan berdampak positif pada pencapaian tujuan perusahaan. Beberapa ahli mengemukakan definisi mengenai kepuasan kerja, diantaranya yaitu : Menurut Rivai (2011:856) mengatakan kepuasan kerja adalah evaluasi yang menggambarkan seseorang atas perasaan sikapnya senang atau tidak senang, puas atau tidak puas dalam bekerja. Sedangkan menurut Tiffin (dalam Sutrisno, 2010:81), mengemukakan kepuasan kerja berhubungan erat dengan sikap dari karyawan terhadap pekerjaannya sendiri, situasi kerja, kerja sama antara pimpinan dengan sesame karyawan.

Bagi organisasi, suatu pembahasan tentang kepuasan kerja akan menyangkut usaha- usaha untuk meningkatkan efektivitas organisasi dengan cara membuat efektif perilaku karyawan dalam kerja. Perilaku karyawan yang menompang pencapaian tujuan organisasi adalah merupakan sisi lain yang harus diperhatikan, di samping penggunaan mesin-mesin modern sebagai hasil kemajuan bidang teknologi. Ketidakpuasan karyawan dalam kerja akan mengakibatkan suatu situasi yang tidak menguntungkan baik secara organisasi maupun secara individual. Ketidakpuasan dalam kerja akan dapat menimbulkan perilaku agresif, atau sebaliknya akan menunjukkan sikap menarik diri dari kontak dengan lingkungan sosialnya. Misalnya, dengan mengambil sikap berhenti dari perusahaan, suka bolos dan perilaku lain yang cenderung bersifat menghindari dari aktifitas organisasi. Bentuk perilaku agresif misalnya melakukan sabotase, sengaja membuat kesalahan dalam kerja, menentang atasan atau sampai pada aktivitas pemogokan. Dari beberapa definisi di atas dapat disimpulkan bahwa kepuasan kerja karyawan adalah merupakan masalah penting yang diperhatikan dalam hubungannya dengan produktivitas kerja karyawan dan ketidakpuasan sering dikaitkan dengan tingkat tuntutan dan keluhan pekerjaan yang tinggi. Pekerja dengan tingkat ketidak puasan yang tinggi lebih mungkin untuk melakukan sabotase dan agresi yang pasif.

Banyak faktor yang mempengaruhi kepuasan kerja karyawan. Faktor-faktor itu sendiri dalam peranannya memberikan kepuasan kepada karyawan bergantung pada pribadi masing-masing karyawan. Menurut Brown \& Ghiselli (dalam Sutrisno, 2010:84) mengemukakan adanya empat faktor yang menimbulkan kepuasan kerja, yaitu: (1) Kedudukan, umumnya manusia beranggapan bahwa seseorang yang bekerja pada pekerjaan yang lebih tinggi akan merasa lebih puas daripada mereka yang bekerja pada pekerjaan yang lebih rendah. Pada beberapa penelitian menunjukkan bahwa hal tersebut tidak selalu benar, tetapi justru perubahan dalam tingkat pekerjaanlah yang mempengaruhi kepuasan kerja. (2) Pangkat, pada pekerjaan yang mendasarkan perbedaan tingkat atau golongan, sehingga pekerjaan tersebut memberikan kedudukan memberikan kedudukan tertentu pada orang yang melakukannya. Apabila ada kenaikan pangkat, dan kebanggaan terhadap kedudukan yang baru itu akan mengubah 
perilaku dan perasaannya. (3) Jaminan finansial dan jaminan sosial, berpengaruh terhadap kepuasan kerja. (4) Mutu pengawasan, hubungan antara karyawan dengan pihak pimpinan sangat penting artinya dalam menaikkan produktivitas kerja. Kepuasan dapat ditingkatkan melalui perhatian dan hubungan yang baik dari pimpinan kepada bawahan, sehingga karyawan akan merasa bahwa dirinya merupakan bagian yang penting dari organisasi kerja. Berdasarkan pada pandangan ini, seseorang karyawan akan merasa puas dalam kerja apabila tidak terdapat perbedaan atau selisih antara apa yang dikehendaki karyawan, dengan kenyataannya yang mereka rasakan. Andaikata yang dirasakan dan diperoleh lebih besar dari apa yang menurut mereka harus ada, maka terjadi tingkat kepuasan yang makin tinggi. Sebaliknya apabila kenyataan yang dirasakan lebih rendah dari apa yang menurut mereka harus ada, maka telah terjadi ketidakpuasan karyawan terhadap kerja. Makin besar perbedaannya ini akan makin besar pula ketidakpuasan karyawan. Dari berbagai pendapat diatas, dapat disimpulkan bahwa faktor-faktor yang mempengaruhi kepuasan kerja, yaitu: (1) Faktor fisik, merupakan faktor yang berhubungan dengan kondisi fisik karyawan, meliputi jenis pekerjaan, pengaturan waktu dan waktu istirahat, perlengkapan kerja, keadaan ruangan, suhu, penerangan, pertukaran udara, kondisi kesehatan karyawan, umur, dan sebagainya. (2) Faktor finansial, merupakan faktor yang berhubungan dengan jaminan serta kesejahteraan karyawan yang meliputi sistem dan besarnya gaji, jaminan sosial, macam-macam tunjangan, fasilitas yang diberikan, promosi, dan sebagainya. (3) Faktor sosial, merupakan faktor yang berhubungan dengan interaksi sosial baik antara sesama karyawan, maupun dengan atasannya.

\section{Teori Perputaran Karyawan}

Dalam setiap kegiatannya, perusahaan menggunakan sumber daya manusia untuk mengelola setiap aktivitas perusahaan. Sebagai mahluk hidup, sumber daya manusia (karyawan) memiliki keterbatasan kemampuan, baik fisik maupun non fisik. Adanya keterbatasan kemampuan tersebut menyebabkan karyawan memiliki batas lama kerja pada perusahaan sehingga pada suatu saat, karyawan tersebut pasti meninggalkan perusahaan. Perusahaan senantiasa berusaha agar proses produksinya berjalan sebagaimana mestinya, sehingga apabila ada karyawan yang meninggalkan perusahaan, maka pihak manajemen akan berusaha untuk menutupi kekurangan karyawan tersebut, melalui rekrutmen.

Menurut Ranupandojo dan Husnan (2001:32), perputaran (turnover) karyawan diartikan sebagai aliran para karyawan yang masuk dan keluar perusahaan. Perputaran karyawan merupakan petunjuk kestabilan karyawan, dimana semakin tinggi turnover, berarti semakin sering terjadi pergantian karyawan. Selanjutnya Flippo (2001:22) menyebutkan bahwa pergantian tenaga kerja merujuk pada perpindahan karyawan ke dalam dan keluar dari suatu organisasi, dan perpindahan tersebut adalah suatu indeks stabilitas tenaga kerja.

Berdasarkan definisi di atas, dapat disimpulkan bahwa perputaran karyawan adalah aliran perpindahan atau pemberhentian dan penerimaan karyawan dalam suatu perusahaan. Perputaran karyawan menunjukkan stabilitas kerja dalam perusahaan. Perputaran karyawan (labour turnover) dapat dihitung dengan cara sebagai berikut (Hasibuan,2005:32): 


$$
\text { Turnover }=\frac{\left.\sum \text { karyawan (yang keluar }+ \text { yang masuk }\right)}{\left.1 / 2 \sum \text { karyawan (awal tahun }+ \text { akhir tahun }\right)} \times 100 \%
$$

Semakin tinggi angka turnover maka stabilitas kerja dalam perusahaan semakin rendah dan sebaliknya, semakin rendah angka turnover, stabilitas kerja dalam perusahaan semakin tinggi. Dengan demikian, perusahaan selalu berusaha untuk menekan angka turnover agar stabilitas kerja dalam perusahaan tetap terjaga sesuai dengan ketentuan.

Menurut Woods dan Macaulay (dalam Gustafson, 2002:32), ada delapan alasan utama yang menyebabkan tingkat perputaran karyawan pada perusahaan secara umum, yaitu: (a) Rendahnya pembayaran dan benefit. (b) Kurangnya kualitas pengawasan. (c) Komunikasi yang kurang efektif. (d) Kondisi kerja yang kurang nyaman. (e) Kurangnya kualitas rekan sekerja. (f) Ketidak cocokan dengan "budaya" perusahaan. (g) Kurangnya definisi dan tanggung jawab yang jelas tentang pekerjaan. (h) Pengarahan yang kurang jelas untuk hal yang harus dilakukan.

\section{B. Pengembangan Hipotesis}

\section{Pengaruh Produkitivitas Kerja Terhadap Perputaran Karyawan}

Pada dasarnya setiap individu memiliki tingkat produktivitas yang berbeda-beda sesuai dengan system nilai-nilai yang berlaku pada dirinya. Semakin banyak aspekaspek dalam pekerjaan sesuai dengan keinginan individu tersebut maka semakin tinggi tingkat produktivitas kerja dirasakan dan sebaliknya. McNeese-Smith (2002:40) menguji pengaruh produktivitas kerja karyawan terhadap perputaran karyawan dimana hasil penelitiannya menunjukkan bahwa produktivitas kerja karyawan berpengaruh negatif atau berlawanan arah terhadap perputaran karyawan yaitu apabila terjadi kenaikkan pada produktivitas kerja akan menyebabkan penurunan pada perputaran karyawan dan sebaliknya apabila terjadi penurunan pada produktivitas kerja akan menyebabkan kenaikkan perputaran karyawan.

H1 : Produktivitas kerja berpengaruh terhadap perputaran karyawan.

\section{Pengaruh Efisiensi Kerja Terhadap Perputaran Karyawan}

Secara umum pengertian efisiensi kerja adalah perbandingan terbaik antara suatu pekerjaan yang dilakukan dengan hasil yang dicapai oleh pekerjaan tersebut sesuai dengan yang ditargetkan baik dalam hal mutu maupun hasilnya. Menurut Miraza (2004:25) efisiensi kerja adalah pemakaian biaya atau bentuk pengorbanan lainnya dari setiap komponen pada setiap aktivitas usaha yang berjalan secara wajar. Komponen tersebut meliputi biaya, waktu, dan tenaga kerja. Perbandingan terbaik antara usaha dan hasilnya dalam setiap pekerjaan terutama ditentukan oleh bagaimana pekerjaan itu dilakukan. Jika efisiensi kerja pada umumnya merupakan hasil dari cara-cara kerja yang sesuai dengan prosedur kerja maka menyebabkan perubahan terhadap perpuataran karyawan dan pengaruhnya bersifat negatif atau berlawanan arah yaitu apabila terjadi kenaikkan pada efisiensi kerja akan menyebabkan penurunan pada perputaran karyawan dan sebaliknya.

$\mathrm{H} 2$ : Efisiensi kerja berpengaruh terhadap perputaran karyawan. 


\section{Pengaruh Kepuasan Kerja Terhadap Perputaran Karyawan}

Kepuasan kerja pada karyawan memiliki arti yang sangat penting bagi perusahaan. Karyawan yang merasa puas pastinya akan bertahan di perusahaan itu dan mampu bekerja secara produktif. Ketidakpuasan kerja telah sering diindentifikasikan sebagai suatu alasan yang penting yang menyebabkan individu meninggalkan pekerjaannya. Novaliadi (2007:197) mengemukakan bahwa kepuasan kerja memiliki hubungan erat terhadap pikiran untuk berhenti kerja dan untuk mencari pekerjaan lain. Intensi untuk berhenti pada akhirnya memiliki hubungan signifikan terhadap perputaran karyawan sebenarnya. Robbins (2003:56) menjelaskan bahwa kepuasan kerja dihubungkan negatif dengan keluarnya karyawan, tetapi faktor-faktor lain seperti pasar kerja, kesempatan kerja alternatif dan panjangnya masa kerja merupakan kendala penting untuk meninggalkan pekerjaan yang ada.

H3 : Kepuasan kerja berpengaruh terhadap perputaran karyawan.

\section{METODE PENELITIAN}

\section{A. Populasi dan Sampel Penelitian}

Dalam penelitian ini, yang menjadi populasi adalah seluruh karyawan yang sudah tidak aktif bekerja yang berjumlah 159 karyawan. Namun demikian penelitian ini tidak semua populasi diteliti tetapi hanya sebagian saja dari populasi yang diteliti yaitu dibagian marketing saja. Teknik pengambilan sampel dengan menggunakan metode simple random sampling (sampel acak sederhana) peneliti mengambil jumlah sampel sebanyak 114 karyawan.

\section{B. Variabel dan Definisi Operasional Variabel}

\section{Variabel Bebas (independent variable)}

Variabel ini sering disebut sebagai variabel stimulus, predictor, antecedent. Dalam bahasa Indonesia sering disebut varaibel bebas. Variabel bebas merupakan variabel yang mempengaruhi atau yang menjadi sebab perubahannya atau timbulnya variabel dependen (Sugiyono, 2014:96). Variabel bebas dalam penelitian ini adalah :

B1 : Produktivitas Kerja

B2 : Efisiensi Kerja

B3 : Kepuasan Kerja

\section{Variabel Terikat (dependent variable)}

Variabel ini sering disebut sebagai variabel output, criteria, konsekuen. Dalam bahasa Indonesia sering disebut sebagai variabel terikat. Variabel terikat merupakan variabel yang dipengaruhi atau yang menjadi akibat, karena adanya variabel bebas (Sugiyono, 2014:97). Variabel terikat dalam penelitian ini adalah Perputaran Karyawan yang selanjutnya diberi notasi PK.

\section{Definisi Operasional Variabel}

Definisi operasional variabel menurut Sugiyono (2008:32) adalah suatu pernyataan yang dapat mengartikan atau memberikan makna untuk suatu istilah atau konsep tertentu, sehingga tidak salah dimengerti. Definisi operasional mengubah konsep atau variabel yang abstrak dengan kata-kata yang menggambarkan tingkah laku atau gejala 
yang dapat diamati, diuji, atau ditentukan kebenarannya oleh orang lain. Dengan kata lain definisi operasional variabel mengubah konsep atau variabel yang abstrak ke tingkat yang lebih realistis, konkrit sehingga gejala tersebut mudah dikenal. Adapun definisi variabel yang digunakan dalam penelitian ini adalah sebagai berikut :

\section{a. ProduktivitasKerja}

Produktivitas kerja adalah kemampuan karyawan dalam berproduksi dibandingkan dengan input yang digunakan, seorang karyawan bisa dikatakan produktif apabila mampu menghasilkan jasa sesuai dengan diharapkan dalam waktu yang singkat atau tepat. Untuk mengukur produiktivitas kerja dengan menggunakan indikator-indikator sebagai berikut (Sutrisno, 2010:111) : (1) Kemampuan, mempunyai kemampuan untuk melaksanakan tugas. Kemampuan seorang karyawan sangat bergantung pada keterampilan yang dimiliki serta profesionalisme mereka dalam bekerja. (2) Meningkatkan hasil yang dicapai, berusaha untuk meningkatkan hasil yang dicapai. Hasil merupakan salah satu yang dapat dirasakan baik oleh yang mengerjakan maupun yang menikmati hasil pekerjaan tersebut. (3) Semangat kerja, ini merupakan usaha untuk lebih baik dari hari kemarin. Indikator ini dapat dilihat dari etos kerja dan hasil yang dicapai dalam satu hari kemudian dibandingkan dengan hari sebelumnya. (4) Pengembangan diri, senantiasa mengembangkan diri untuk meningkatkan kemampuan kerja. Pengembangan diri dapat dilakukan dengan meilhat tantangan dan harapan dengan apa yang akan dihadapi. (5) Mutu, selalu berusaha untuk meningkatkan mutu lebih baik dari yang telah lalu. Mutu merupakan hasil pekerjaan yang dapat menunjukkan kualitas kerja seorang pegawai. (6) Efisiensi, perbandingan antara hasil yang dicapai dengan keseluruhan sumber daya yang digunakan. Masukan dan keluaran merupakan aspek produktivitas yang memberikan pengaruh yang cukup signifikan bagi karyawan.

\section{b. EfisiensiKerja}

Efisiensi kerja adalah tingkat kinerja yang menggambarkan suatu proses yang menggunakan sedikit input untuk menciptakan output yang lebih besar. Efisiensi berkaitan dengan penggunaan semua input dalam memproduksi output, termasuk waktu pribadi dan energi. Adapun indikator efisiensi kerja menurut Syamsi (2007:50) sebagai berikut : (1) Mengerti latar belakang dan tujuan dari pekerjaan yang dilakukan. (2) Membuat perencanaan pekerjaan termasuk berapa lama waktu yang ditargetkan. (3) Bagi pekerjaan-pekerjaan besar menjadi pekerjaan-pekerjaan kecil. (4) Kenali kemampuan diri dan jangan malu belajar dari orang lain. (5) Semangat pantang menyerah dan saling menguatkan.

\section{c. KepuasanKerja}

Kepuasan kerja adalah sikap yang positif dari karyawan meliputi perasaan dan tingkah laku terhadap pekerjaannya melalui penilaian salah satu pekerjaan sebagai rasa menghargai dalam mencapai salah satu nilai-nilai penting pekerjaan. Beberapa indikator yang dapat digunakan untuk menilai kepuasan kerja (Robbins, 2003:148), yaitu: (1) Kepuasan terhadap pekerjaan. (2) Kepuasan terhadap gaji. (3) Kepuasan terhadap promosi. (4) Kepuasan terhadap pengawas. (5) Kepuasan terhadap rekan kerja.

\section{d. Perputaran Karyawan(PK)}

Perputaran karyawan adalah pergerakan keluar masuknya karyawan dalam suatu organisasi. Sedangkan standar tingkat perputaran karyawan yang biasa ditolerir sangat 
bergantung dari sudut pandang tiap-tiap pribadi dan komunitas tertentu. Adapun indikator yang dipergunakan untuk mengetahui perputaran karyawan menurut Rivai (2004:475) meliputi : (1) Komitmen organisasi, seorang karyawan yang punya komitmen terhadap organisasi akan mempengaruhinya secara kuat untuk tetap bertahan di perusahaannya. (2) Peluang jangka panjang, dalam hal ini bagaimana seseorang melihat masa depannya di perusahaan. Karyawan akan bertahan bila peluang pendidikan dan karir diberikan oleh perusahaan. (3) Kepuasan kerja, seorang karyawan yang mempunyai kepuasan kerja tinggi tidak akan meninggalkan perusahaan, namun juga berlaku sebaliknya. (4) Stress kerja, jika karyawan mengalami stress tinggi, maka cenderung akan meninggalkan perusahaan. (5) Keadilan, perlakuan secara adil bagi seluruh karyawan akan meneguhkan karyawan semakin loyal terhadap perusahaan dan akan tetap bertahan.

\section{HASIL PENELITIAN DAN PEMBAHASAN}

Populasi yang digunakan dalam penelitian ini adalah karyawan yang telah mengundurkan diri dari PT. Bank Mega, Tbk Regional Office Surabaya bagian marketing yang berjumlah 114 karyawan yang dijadikan responden. Gambaran subyek penelitian dilakukan dengan menguraikan karakteristik responden sebagai subyek penelitian, yang meliputi jenis kelamin, usia, pendidikan dan lama bekerja. Hal ini digunakan untuk mengungkapkan indentitas responden yang diintepretasikan dari hasil pengolahan data melalui tabulasi frekuensi guna menghitung kecenderungan nominal empirik.

\section{A. Hasil Uji Kualitas Data}

\section{Uji Validitas}

Validitas menunjukkan sejauh mana perbedaan yang didapatkan melalui alat pengukur mencerminkan perbedaan yang sesungguhnya diantara responden yang diteliti. Dalam hal ini digunakan beberapa butir pertanyaan yang dapat secara tepat mengungkapkan variabel yang diukur tersebut. Jika suatu item memiliki nilai capaian koefisien korelasi minimal 0,30 dianggap memiliki daya pembeda yang cukup memuaskan atau dianggap valid. Berikut hasil uji validitas yang disajikan pada tabel 1 berikut:

Tabel 1 : Hasil Uji Validitas

\begin{tabular}{ccccc}
\hline Variabel & Pernyataan & Koef. Korelasi & Korelasi Minimal & Keterangan \\
\hline & Prodk 1 & 0,864 & 0,3 & Valid \\
& Prodk 2 & 0,878 & 0,3 & Valid \\
Produktivitas & Prodk 3 & 0,795 & 0,3 & Valid \\
Kerja & Prodk 4 & 0,847 & 0,3 & Valid \\
& Prodk 5 & 0,724 & 0,3 & Valid \\
& Prodk 6 & 0,777 & 0,3 & Valid \\
\hline \multirow{3}{*}{ Efisiensi } & Eff 1 & 0,774 & 0,3 & Valid \\
Kerja & Eff 2 & 0,816 & 0,3 & Valid \\
& Eff 3 & 0,832 & 0,3 & Valid \\
& Eff 4 & 0,735 & 0,3 & Valid \\
\hline \multirow{2}{*}{ Kenuasan Keria } & Eff 5 & 0,747 & 0,3 & Valid \\
\hline
\end{tabular}




\begin{tabular}{lcccc} 
& Kep 3 & 0,852 & 0,3 & Valid \\
& Kep 4 & 0,805 & 0,3 & Valid \\
& Kep 5 & 0,827 & 0,3 & Valid \\
\hline \multirow{3}{*}{ Perputaran } & PK 1 & 0,903 & 0,3 & Valid \\
Karyawan & PK 2 & 0,848 & 0,3 & Valid \\
& PK 3 & 0,886 & 0,3 & Valid \\
& PK 4 & 0,909 & 0,3 & Valid \\
& PK 5 & 0,865 & 0,3 & Valid \\
\hline
\end{tabular}

Berdasarkan Tabel 1 dapat diketahui bahwa nilai korelasi dari setiap pernyataan pada variabel produktivitas kerja, efisiensi kerja, kepuasan kerja dan perputaran karyawan lebih besar dari 0,3, sehingga dapat disimpulkan bahwa semua pernyataan untuk setiap variabel penelitian telah valid.

\section{Uji Reliabilitas}

Uji reliabilitas merupakan uji yang berkenaan dengan derajat konsistensi atau kehandalan data dalam interval waktu tertentu. Uji reliabilitas dalam penelitian ini menggunakan metode penguji satu kali, lalu dengan cara tertentu diestimasi reliabilitns instrumen. Suatu konstruk atau variabel dikatakan reliabel jika memberikan nilai Cronbach Alpha $\geq 0,60$. Berikut hasil pengujian reliabilitas yang disajikan pada Tabel 2 berikut:

Tabel 2 : Hasil UjiReliabilitas

\begin{tabular}{lcc}
\hline Variabel & Koefisien Alpha & Keterangan \\
\hline Produktivitas kerja (Prodk) & 0,89 & Reliabel \\
Efisiensi kerja (Eff) & 0,83 & Reliabel \\
Kepuasan kerja (Kep) & 0,86 & Reliabel \\
Perputaran karyawan(PK) & $\underline{0,929}$ & Reliabel \\
\hline
\end{tabular}

Berdasarkan dari Tabel 2 diatas menunjukkan bahwa variabel produktivitas kerja, efisiensi kerja, kepuasan kerja dan perputaran karyawan mempunyai nilai cronbach alpha lebih dari 0,60. Dengan demikian berarti bahwa item pernyataan untuk semua variabel tersebut dinyatakan reliabel.

\section{B. Analisis Deskriptif}

Analisis data secara deskriptif ini menguraikan hasil analisis terhadap responden dengan menguraikan gambaran data tentang 114 responden. Analisis ini digunakan untuk mendeskripsikan nilai-nilai dari kuesioner pada masing-masing variabel. Setelah itu dilanjutkan dengan menghitung mean untuk variabel bebas dan menganalisis tanggapan dari responden kuesioner yang diolah. Berdasarkan hasil pengumpulan data dari responden, maka diperoleh gambaran obyek dari variabel-variabel yang digunakan dalam penelitian ini. Pengukuran variabel menggunakan ukuran skala likert 1 sampai dengan 5. Untuk menentukan nilai rata-rata dari masing-masing responden terhadap setiap pernyataan, maka dilakukan dengan cara menjumlah nilai jawaban tersebut dibagi dengan masing-masing jumlah indikator dalam setiap variabel. Untuk mempermudah penilaian maka dibuat kategori penilaian, dimana penentuan interval kelasnya telah ditetapkan melalui rumus sebagai berikut:

$$
\text { IntervalKelas }=\frac{\mathrm{NT}-\mathrm{NTr}}{\mathrm{JK}}=\frac{5-1=0}{5}, 8
$$


Keterangan :

NT : Nilai Tertinggi

JK : Jumlah Kelas

NTr : Nilai Terendah

Dari interval kelas diatas, maka dapat diketahui batasan masing-masing skala yang dapat dilihat pada tabel dibawah ini :

Tabel 3 : Interval Kelas

\begin{tabular}{ccc}
\hline Interval & Nilai & Kategori \\
\hline $1<X<1,8$ & 1 & Sangat Tidak \\
$1,8<X<$ & 2 & Tidak Setuju \\
$2,6<X<$ & 3 & Cukup Setuju \\
$3,4<X<$ & 4 & Setuju \\
$4,2<X<5$ & 5 & Sangat Setuju \\
\hline Sumber : Sugiyono. 2008. Metode Penelitian Bisnis.
\end{tabular}

Setelah ditentukan interval kelas, maka selanjutnya akan ditampilkan skor tanggapan responden terhadap ariable-variabel yang diteliti.

\section{Analisis Tanggapan Responden Terhadap Produktivitas kerja}

Diketahui dari data kuesioner yang telah dilakukan tabulasi sebelumnya, maka dapat dilakukan analisis tanggapan responden terhadap enam item pernyataan pada variabel produktivitas kerja sebagai berikut:

Tabel 4 :

Tanggapan Responden Terhadap Variabel Produktivitas kerja

\begin{tabular}{|c|c|c|c|c|c|c|c|}
\hline \multirow{2}{*}{ PERNYATAAN - } & \multicolumn{5}{|c|}{ SKALA JAWABAN } & \multirow{2}{*}{ TOTAL } & \multirow{2}{*}{ MEAN } \\
\hline & 1 & 2 & 3 & 4 & 5 & & \\
\hline Prodk 1 & 0 & 14 & 33 & 43 & 24 & 114 & 3,68 \\
\hline Prodk 2 & 0 & 10 & 32 & 36 & 36 & 114 & 3,86 \\
\hline Prodk 3 & 0 & 10 & 25 & 46 & 33 & 114 & 3,89 \\
\hline Prodk 4 & 0 & 10 & 26 & 48 & 30 & 114 & 3,86 \\
\hline Prodk 5 & 1 & 9 & 36 & 30 & 38 & 114 & 3,83 \\
\hline Prodk 6 & 0 & 10 & 34 & 37 & 33 & 114 & 3,82 \\
\hline
\end{tabular}

Tabel 4 menunjukkan bahwa pada variabel produktivitas kerja. Mayoritas responden menyatakan "Setuju", hal ini menunjukkan bahwa sebagian besar responden sudah mempunyai produktivitas yang cukup baik.

\section{Analisis Tanggapan Responden Terhadap Efisiensi kerja}

Diketahui dari data kuesioner yang telah dilakukan tabulasi sebelumnya, maka dapat dilakukan analisis tanggapan responden terhadap lima item pernyataan pada ariable efisiensi kerja sebagai berikut:

Tabel 5 : Tanggapan Responden Terhadap Variabel Efisiensi kerja

\begin{tabular}{|c|c|c|c|c|c|c|c|}
\hline \multirow{2}{*}{ PERNYATAAN } & \multicolumn{5}{|c|}{ SKALA JAWABAN } & \multirow{2}{*}{ TOTAL } & \multirow{2}{*}{ MEAN } \\
\hline & 1 & 2 & 3 & 4 & 5 & & \\
\hline Eff1 & 0 & 20 & 32 & 50 & 12 & 114 & 3,47 \\
\hline Eff2 & 0 & 7 & 38 & 39 & 30 & 114 & 3,80 \\
\hline Eff3 & 0 & 10 & 36 & 44 & 24 & 114 & 3,72 \\
\hline Eff4 & 0 & 11 & 35 & 38 & 30 & 114 & 3,76 \\
\hline Eff5 & 0 & 11 & 28 & 47 & 28 & 114 & 3,81 \\
\hline
\end{tabular}


Tabel 5 menunjukkan bahwa pada ariable efisiensi kerja. Mayoritas responden menyatakan "Setuju", hal ini menunjukkan bahwa sebagian besar responden sudah cukup efisien dalam bekerja.

\section{Analisis Tanggapan Responden Terhadap Kepuasankerja}

Diketahui dari data kuesioner yang telah dilakukan tabulasi sebelumnya, maka dapat dilakukan analisis tanggapan responden terhadap lima item pernyataan pada ariable kepuasan kerja sebagai berikut:

Tabel 6

Tanggapan Responden Terhadap Variabel Kepuasan kerja

\begin{tabular}{|c|c|c|c|c|c|c|c|}
\hline \multirow{2}{*}{ PERNYATAAN } & \multicolumn{5}{|c|}{ SKALA JAWABAN } & \multirow{2}{*}{ TOTAL } & \multirow{2}{*}{ MEAN } \\
\hline & 1 & 2 & 3 & 4 & 5 & & \\
\hline Kep & 0 & 10 & 3 & 4 & 24 & 114 & 3,73 \\
\hline Kep & 0 & 9 & 2 & 5 & 17 & 114 & 3,74 \\
\hline Kep & 0 & 6 & 3 & 3 & 35 & 114 & 3,90 \\
\hline Kep & 0 & 7 & 2 & 4 & 33 & 114 & 3,95 \\
\hline Kep & 0 & 8 & 3 & 3 & 41 & 114 & 3,94 \\
\hline
\end{tabular}

Tabel 6 menunjukkan bahwa pada ariable kepuasan kerja. Mayoritas responden menyatakan "Setuju", hal ini menunjukkan bahwa sebagain besar responden cukup puas dengan apa yang dikerjakan sekarang ini.

\section{Analisis Tanggapan Responden Terhadap Perputarankaryawan}

Diketahui dari data kuesioner yang telah dilakukan tabulasi sebelumnya, maka dapat dilakukan analisis tanggapan responden terhadap lima item pernyataan pada variabel perputaran karyawan sebagai berikut:

Tabel 7

Tanggapan Responden Terhadap Variabel Perputaran karyawan

\begin{tabular}{|c|c|c|c|c|c|c|c|}
\hline \multirow{2}{*}{ PERNYATAAN } & \multicolumn{5}{|c|}{ SKALA JAWABAN } & \multirow{2}{*}{ TOTAL } & \multirow{2}{*}{ MEAN } \\
\hline & 1 & 2 & 3 & 4 & 5 & & \\
\hline PK. & 0 & 17 & 30 & 43 & 24 & 114 & 3,6 \\
\hline PK. & 0 & 12 & 25 & 40 & 37 & 114 & 3,8 \\
\hline PK. & 1 & 16 & 33 & 34 & 30 & 114 & 3,6 \\
\hline PK. & 0 & 16 & 33 & 30 & 35 & 114 & 3,7 \\
\hline PK. & 0 & 13 & 31 & 33 & 37 & 114 & 3,8 \\
\hline
\end{tabular}

Tabel 7 menunjukkan bahwa pada variabel perputaran karyawan. Mayoritas responden menyatakan "Setuju", hal ini menunjukkan bahwa bahwa sebagian besar responden mempunyai keinginan untuk tetap di perusahaan.

\section{B. Uji Asumsi Klasik}

\section{Uji Multikolinieritas}

Pengujian ini untuk mengetahui apakah antar variabel bebas dalam persamaan regresi tersebut tidak saling berkorelasi. Gejala multikolinearitas dapat diketahui melalui suatu uji yang dapat mendeteksi dan menguji apakah persamaan yang dibentuk terjadi gejala multikolinearitas adalah dengan menggunakan atau melihat alat uji yang disebut Variance Inflation Factor (VIF). Pedoman dalam melihat apakah suatu variabel bebas memiliki korelasi dengan variabel bebas yang lain dapat dilihat berdasarkan nilai VIF 
tersebut. Jika nilai VIF $<10$, ini menunjukkan model tidak terdapat gejala multikolinearitas, artinya terdapat hubungan antar variabel bebas. (Algifari dan Wibowo, 2012:87). Hasil uji multikolinieritas dapat dilihat pada tabel di bawah ini:

Tabel 8 : Hasil Uji Multikolinieritas

\begin{tabular}{cccc} 
Variabel & Tolerance & VIF & Keterangan \\
\hline Produktivitas kerja & 0,543 & 1,840 & Non Multikolinearitas \\
Efisiensi kerja & 0,529 & 1,890 & Non Multikolinearitas \\
Kepuasankerja & $\underline{0,499}$ & $\underline{2,002}$ & Non Multikolinearitas \\
\cline { 1 - 1 } & & &
\end{tabular}

Berdasarkan pada tabel 8 di atas menunjukkan bahwa seluruh variabel bebas $(X)$ yang digunakan dalam penelitian ini mempunyai nilai VIF (Variance Inflation Factor) < 10, maka hal ini berarti dalam persamaan regresi tidak ditemukan adanya korelasi antar variabel bebas atau bebas multikolinieritas, sehingga seluruh variabel bebas $(X)$ tersebut dapat digunakan dalam penelitian.

\section{Uji Heterokedastisitas}

Pada penelitian ini uji heteroskedastisitas yang digunakan adalah uji Glejser dengan cara mengorelasikan nilai absolute residualnya dengan masing-masing variabel independen. Jika hasil nilai probabilitasnya memiliki nilai signifikansi > nilai alphanya $(0,05)$, maka model tidak mengalami heteroskedastisitas. Hasil pengujian heterokedastisitas dapat dilihat pada tabel di bawahini:

Tabel 9 : Hasil Uji Korelasi Heterokedastisitas

\begin{tabular}{lcc}
\hline \multicolumn{1}{c}{ Variabel } & Signifikan & Keterangan \\
\hline Produktivitas kerja & 0,584 & Non Heterokedastisitas \\
Efisiensi kerja & 0,595 & Non Heterokedastisitas \\
Kepuasan kerja & 0,598 & Non Heterokedastisitas \\
\hline
\end{tabular}

Pada uji rank spearman's correlation test nilai siginifikan keempat variabel $>0,05$ maka tidak terjadi heterokesdasitas, artinya penganggu dalam persamaan regresi mempunyai varian yang sama.

\section{Uji Normalitas}

Uji normalitas adalah uji yang ditujukan untuk menguji apakah sebuah regresi, variabel terikat dan variabel bebas keduanya mempunyai distribusi normal atau tidak. Model regresi yang baik adalah distribusi data normal atau mendekati normal. Hasil Uji normalitas dapat dilihat pada tabel di bawah ini :

Tabel 10 : Hasil Uji Normalitas

One-Sample Kolmogorov-Smirnov Test

\begin{tabular}{lc}
\hline & Unstandardized Residual \\
\hline $\mathrm{N}$ & 114 \\
Kolmogorov-Smirnov Z & .957 \\
Asymp. Sig. (2-tailed) & .319 \\
\hline
\end{tabular}

a. Test distribution is Normal.

Berdasarkan tabel di atas dapat diketahui bahwa nilai Asymp. Sig sebesar 0,319 $>0,05$, sehingga data yang digunakan dalam penelitian ini sudah berdistribusi normal, maka persamaan model regresi linier berganda memenuhi asumsi normalitas. 


\section{Analisis Regresi Linier Berganda}

Analisis regresi linear berganda digunakan untuk mengetahui seberapa besar pengaruh variabel bebas yaitu produktivitas kerja (Prodk), efisiensi kerja (Eff) dan kepuasan kerja (Kep) terhadap variabel terikat yaitu perputaran karyawan (PK). Berikut ini akan disajikan hasil dari pengolahan data dengan menggunakan program SPSS versi 16 for windows yang ditunjukkan pada tabel 11 berikut ini:

Tabel 11 : Regresi LinearBerganda

\begin{tabular}{lclc}
\hline \multicolumn{1}{c}{ Variabel } & Koefisien & $\mathbf{t}_{\text {hituna }}$ & Sig \\
\hline Konstanta & 6,837 & - & - \\
Prodk & 0,157 & - & 0,03 \\
Eff & 0,246 & - & 0,04 \\
Kep & 0,212 & - & 0,04 \\
\hline$R=0,576$ & & & \\
$R^{2}=0,332$ & & &
\end{tabular}

Berdasarkan tabel 11, diperoleh persamaan regresi sebagai berikut :

$$
\mathrm{PK}=6,837+0,157 \text { Prodk + 0,246 Eff }+0,212 \mathrm{Kep}+\mathrm{e}
$$

Dari persamaan regresi tersebut dapat diketahui bahwa :

Konstanta sebesar 6,837 menunjukkan bahwa jika produktivitas kerja, efisiensi kerja dan kepuasan kerja $=0$ atau tidak ada, maka perputaran karyawan akan sebesar 6,837 . Kemudian koefisien regresi untuk variabel produktivitas (Prodk) sebesar 0,257, variabel efisiensi kerja (Eff) sebesar -0,271, variabel kepuasan kerja (Kep) sebesar -0,283. Koefisien negatif menunjukkan bahwa variabel produktivitas, efisiensi, kepuasan kerja mempunyai hubungan berlawanan arah dengan perputaran karyawan (PK). Artinya apabila produktivitas, efisiensi, kepuasan kerja (Kep) meningkat akan menyebabkan penurunan terhadap perputaran karyawan dengan asumsi variabel bebas yang lain dalam keadaan konstan.

\section{Koefisien Determinasi Simultan $\left(\mathbf{R}^{2}\right)$}

Koefisien korelasi simultan adalah suatu besaran yang mengukur tingkat keeratan hubungan variabel-variabel bebas secara simultan terhadap niat beli yang disajikan pada tabel 12 berikut:

Tabel 12 : Hasil Perhitungan Koefisien Korelasi dan Determinasi Simultan

\begin{tabular}{ccccc}
\hline Model & $\mathbf{R}$ & $\mathbf{R}$ & Adjusted $\mathbf{R}$ & Std. Error of the \\
\hline 1 & 0,576 & 0,332 & 0,313 & 0,74079 \\
\hline
\end{tabular}

Tabel 12 menunjukkan bahwa nilai koefisien korelasi $(R)$ adalah sebesar 0,576. Nilai tersebut mendekati angka satu, sehingga dapat dinyatakan bahwa hubungan antara variabel-variabel bebas secara simultan terhadap perputaran karyawan adalah cukup erat. Berdasarkan tabel 12 Koefisien Determinasi berganda atau $R$ squared sebesar 0,332 atau $33,2 \%$. Berarti kontribusi secara simultan variabel bebas yaitu produktivitas kerja, efisiensi kerja dan kepuasan kerja adalah sebesar 33,2\% terhadap variabel terikat perputaran karyawan. Sedangkan sisanya sebesar $66,8 \%$ dipengaruhi oleh variabel lain yang tidak termasuk dalam model regresi linier berganda. 


\section{E. Koefisien Korelasi dan Determinasi Parsial}

Koefesien korelasi parsial mengukur tingkat keeratan variabel bebas yang terdiri dari produktivitas kerja, efisiensi kerja, dan kepuasan kerja secara parsial terhadap perputaran karyawan dimana proporsi pengaruh dari masing-masing variabel bebas tersebut dinyatakan oleh nilai koefisien determinasi parsial, disajikan dalam tabel 13 sebagai berikut:

\section{Tabel 13}

Hasil Perhitungan Koefisien Korelasi dan Determinasi Parsial

\begin{tabular}{|c|c|c|}
\hline Variabel & Korelasi Parsial & Determinasi Parsial \\
\hline Produktivitas kerja & $-0,197$ & 0,039 \\
\hline Efisiensi kerja & $-0,189$ & 0,036 \\
\hline Kepuasan kerja & $-0,193$ & 0,037 \\
\hline
\end{tabular}

Pada tabel 13 dapat diketahui bahwa nilai koefesien determinasi tertinggi dicapai oleh variabel produktivitas kerja yaitu sebesar atau 3,9\%. Jadi bisa dikatakan bahwa variable produktivitas kerja merupakan variabel bebas yang dominan mempengaruhi perputaran karyawan.

\section{F. Uji Parsial (Uji t)}

Uji t digunakan untuk menguji mengetahui pengaruh variabel bebas terhadap variabel terikat secara parsial.

Tabel 14 :Hasil Uji t

\begin{tabular}{lcccc}
\hline \multicolumn{1}{c}{ Variabel Bebas } & thitun & Signifikansi & Ho & H1 \\
\hline Produktivitas kerja & $-2,109$ & 0,037 & Ditolak & Diterima \\
Efisiensi kerja & $-2,020$ & 0,046 & Ditolak & Diterima \\
Kepuasan kerja & $-2,058$ & 0,042 & Ditolak & Diterima \\
\hline
\end{tabular}

Dengan Langkah-langkah sebagaiberikut:

(1) Merumuskan hipotesis : $H_{0}=b_{1}=0$, dimana $\mathrm{i}=1,2,3$ secara parsial variabel bebas yang terdiri produktivitas kerja, efisiensi kerja dan kepuasan kerja tidak memiliki pengaruh yang signifikan terhadap perputaran karyawan. $H_{i}=b_{1} \neq 0$, dimana $\mathrm{i}=1,2,3$ secara parsial variabel bebas yang terdiri produktivitas kerja, efisiensi kerja dan kepuasan kerja memiliki pengaruh yang signifikan terhadap perputaran karyawan. (2) Menginterprestasikan hasil : Berdasarkan tabel 14 dapat diketahui bahwa thitung untuk variabel produktivitas kerja (Prodk) sebesar -2,109 dengan tingkat signifikansi sebesar 0,037<0,05 atau 5\%, variabel efisiensi kerja (Eff) sebesar -2,020 dengan tingkat signifikansi sebesar $0,046<0,05$ atau $5 \%$, variabel kepuasan kerja (Kep) sebesar -2,058 dengan tingkat signifikansi sebesar 0,042 <0,05 atau 5\%, sehingga Ho ditolak dan $\mathrm{H} 1$ diterima. Jadi dapat dikatakan bahwa produktivitas, efisiensi, kepuasan kerjamempunyai pengaruh yang signifikan terhadap perputaran karyawan.

\section{G. Uji Kelayakan Model}

Hasil uji kelayakan model antara variabel produktivitas, efisiensi, kepuasan Kerja terhadap perputaran karyawan ditampilkan pada tabel 15 
Tabel 15 : Uji Kelayakan Model

\begin{tabular}{ll}
\hline $\mathbf{F}_{\text {hitung }}$ & Probabilitas signifikansi \\
\hline 18,198 & 0,000 \\
\hline
\end{tabular}

Uji $\mathrm{F}$ anatara variabel produktivitas, efisiensi, kepuasan kerja dengan variabel perputaran karyawan menghasilkan nilai signifikansi sebesar $0,000<0,05$, maka $\mathrm{HO}$ ditolak dan $\mathrm{H} 1$ diterima, sehingga dapat disimpulkan bahwa secara simultan produktivitas, efisiensi, kepuasan kerja mempunyai pengaruh yang signifikan terhadap perputaran karyawan.

Karena nilai $F$ hitung terletak pada nilai signifikansi $0,000<0,05$ maka juga dapat dikatakan bahwa model yang digunakan dalam penelitian ini layak digunakan.

\section{KESIMPULAN DAN SARAN}

\section{A. Kesimpulan}

Dari hasil dan analisis serta pengujian yang telah dilakukan, maka diperoleh kesimpulan hasil penelitian bahwa produktivitas kerja, efisiensi kerja, dan kepuasan kerja baik secara parsial maupun simultan mempunyai pengaruh yang signifikan terhadap variabel dependent, yaitu perputaran karyawan sehingga hipotesis yang peneliti ajukan terbukti kebenarannya. Variabel produktivitas kerja merupakan variabel yang berpengaruh dominan terhadap perputaran karyawan.

\section{B. Saran}

Berdasarkan hasil penilitian di atas, dapat disarankan beberapa hal bagi peneliti lain

yaitu lebih memperhatikan faktor-faktor lain diluar model dalam penelitian ini, seperti kompensasi, dan motivasi kerja dan faktor lain-lain yang memiliki dampak pada perputaran karyawan. Sedangkan bagi perusahaan perlu dipertimbangkan lebih mengembangkan produktivitas kerja dan kepuasan kerja yang tinggi. Hal ini dilakukan untuk memotivasi karyawan perusahaan lebih berkreasi tanpa melanggar aturan yang telah ada pada perusahaan dengan begitu akan semakin meningkatkan produktivitas kerja karyawan.

\section{DAFTAR PUSTAKA}

Algifari dan Wibowo. 2012. Manajemen Kinerja. Rajawali Pers. Jakarta Flippo, E. B. 2001. Manajemen Personalia. Edisi Empat. PT. Erlangga. Jakarta

Ghozali, I. 2011. Aplikasi Analisis Multivariate Dengan Program IBM SPSS 19. Edisi Kelima.Semarang

Grensing, L. 1997. Seleksi Karyawan. Terjemahan. Cetakan Pertama. Arcan. Jakarta.

Gustafson. 2002. Survey of Instructional development Models. New york: Eric Clearing house on information and technology, syracuse University.

Hasibuan, M. S. P. 2005, Manajemen Sumber Daya Manusia, Edisi Revisi. Bumi Aksara. Jakarta.

McNeese-Smith, D. 2002, Increasing Employee Productivity, Job Satisfaction and Organizational Commitment, Hospital \& Health Services Administration, Vol.41 
Miraza. B. H. 2005. Perencanaan dan Pengembangan Wilayah. ISEI.

Bandung. Mulyadi. 2000. Akuntansi Biaya. Edisi 5. Aditya Media.

Yogyakarta.

Novliadi, F. 2007. Perputaran Karyawan ditinjau dari Budaya Perusahaan, Produktivitas Kerja, dan Kepuasan Kerja. Makalah Universitas Sumatra Utara. Medan.

Ranupandojo, H dan S. Husnan. 2001. Manajemen Personalia. Cetakan Ketujuh. BPFE. Yogyakarta.

Rivai. V. 2004. Manajemen Sumber Daya Manusia Untuk Perusahaan. Cetakan Pertama. PT. Raja Grafindo. Jakarta , 2011. Manajemen Sumber Daya Manusia Untuk Perusahaan Dari Teori Ke Praktek. PT. Raja Grafindo Persada.Jakarta.

Robbins, S. P. 2003. Perilaku organisasi. PT. Indeks Kelompok GRAMEDIA. Jakarta. Sedarmayanti. 2001. Sumber Daya Manusia dan Produktivitas Kerja. Mnadar Maju.

Bandung.

Siagian, S. P. 2003. Teori dan Praktek Kepemimpinan. Cetakan Keliama. Rineka Cipta.

Jakarta.

, 2006. Sistem Informasi Manajemen. PT. Bumi Aksara.Jakarta.

Sugiyono, 2008. Metode Penelitian Kuantitatif, Kualitatif dan Kombinasi (Mixed Methods).

Alfabeta. Bandung. , 2014. Cara Mudah untuk Menulis Skripsi, Tesis dan Disertasi.

Alfabeta.

Bandung.

Sutrisno, E. 2010. Manajemen Sumber Daya Manusia. PT Prenada Media Group. Jakarta. Syamsi, I. 2007. Efisiensi, Sistem, dan Prosedur Kerja. Bumi Aksara. Sekolah Tinggi IImu

MAnajemen YKPN. Jakarta. 